\title{
CHANGES IN THE GOVERNMENT OF INDIA
}

\author{
By Sir Denys Bray, K.C.S.I., K.C.I.E., C.B.E. \\ ForMerly, Foreign SeCretary, GovernMent of India
}

$\mathrm{O}^{\mathrm{N}}$ $\mathrm{N}$ July 22 the Viceroy of India made an announcement that came as a great relief to many in Great Britain who had been chafing under our apparent inability to do anything to relieve the political deadlock in India. It was a notable announcement; yet its wording was studiously matter-of-fact. It merely stated that as a result of the increased pressure of work in connexion with the War it had been decided to enlarge the Executive Council of the Governor-General of India, and to establish a National Defence Council in order to associate Indian non-official opinion so far as possible with the prosecution of the war ; and then followed the names of seven Indians who were to join the former and of twenty Indians who (with two non-Indians) were to represent British India on the latter.

To those in Great Britain with no knowledge of the working of the Government of India, the Viceroy's announcement can have conveyed little of its true significance. When Mr. Amery in a weighty speech expounded these changes in the House of Commons, his statement was received with calm satisfaction, tempered only by expressions of regret that they did not go further. The House seemed scarcely conscious that anything out of the way had been enacted; indeed the Secretary of State was at pains to emphasize that the changes involved no alteration in the constitution but were merely administrative changes, interim measures taken within the existing framework. Yet it may be doubted whether these changes will not figure in history as in some ways an even more significant milestone on India's road to full nationhood than the great constitutional change embodied in the Government of India Act of 1935 after months of heated debate. For that Act, while it brought self-government to the eleven Provinces of British India, left the Central Government for the time being untouched. But the changes now so modestly introduced affect the working of the Central Government itself.

For the Viceroy's Council is no mere advisory body. In the Governor-General in Council, to use the technical term, is vested the supreme authority in India. The Council is in fact a Cabinet with collective work and responsibility, composed of Ministers-or Members as they are called-each in control of one of the great Government departments, the Viceroy himself being member for foreign affairs. During the first fifty years of its being the Council was purely British in composition. Not until 1909 was an Indian appointed; not until 1920 was the number of Indians raised to three; and now the Viceroy is to preside over a Cabinet with Indians in a majority of two to one. It is a transformation that would have made Lord Curzon stare and gasp. That it evoked not a word of dissent in Parliament (except on the score that it did not go far enough) and scarcely a word of criticism in the Press is significant of the wholesale and very wholesome change that in half a dozen years has come over political thought in Great Britain. It is to be hoped that a very full report of the debate and the subsequent Press comments was telegraphed to India. The warm-hearted spirit in which the changes have been welcomed in Great Britain is likely to prove more acceptable to political India than the changes themselves.

No one with any knowledge of the political currents in India to-day could be so sanguine as to expect a general welcome from India for any changes which do not involve a formal change in the constitution. We in Great Britain pride ourselves on the vitality and unseen growth of our own unwritten constitution, and are inclined to eye written constitutions not a little impatientlyif indeed we can bring ourselves to study them at all-and to judge them not by the written letter but solely by the spirit in which they are worked. Naturally enough, it is otherwise with Indians. Accustomed as they are to a written constitution, they look jealously at every letter in it, and are apt to assume that the checks and safeguards every written constitution must perforce contain are a faithful reflex of its everyday working. Though the present changes, as Mr. Amery told the House, are a signal "earnest of our desire to transfer to Indian hands a steadily increasing share in the control of India's destiny", they are interim adjustments only, pending the day when Indians are able to accept our invitation "by agreement among themselves to devise the framework of the Indian constitution in accordance with the social, economic and political structure of Indian life". The changes mark an abiding and far-reaching change in the spirit of the constitution; and it is history's lesson that in the life of a nation it is the spirit that quickens. But great though the change in the spirit, the letter of the constitution remains unchanged. The Governor- 
General in Council, though the supreme authority in India, is still responsible to the Secretary of State for India and ultimately to Parliament However responsive the Council may be to the Indian Assembly-and with Indians in an overwhelming majority it is a foregone conclusion that its responsiveness will be very sensibly quickenedits members are not responsible to it ; nor can the Assembly turn them out of office. Hence, with the constitution left unaltered, the All India Congress declined to have anything to do with these interim measures or to allow its adherents to join the Council. The Muslim League, though glad enough that the constitution has been left for the time being as it is, laid down conditions for its own participation too exacting for acceptance.

It is, of course, a misfortune for India and for the British Commonwealth that neither of the two leading parties is formally represented on the Executive Council. Yet the Council will contain men who, abating nothing of their robust nationalist patriotism, have only dissociated themselves from their party over the non-constructive tactics it is pursuing. Happily, India has no dearth of public men of ability; and among the new members - of whom three are Hindus, bringing the number of Hindus on the Council to four, three are Muslims and one a Parsee-are men who have made their mark in India, and are not unknown in Great Britain and in the United States and at Geneva. Together they form a strong reinforcement to the Council.

How well off India is for public men may be seen from the names in the long list of appointments to the National Defence Council. This is an entirely new body. Unlike the Viceroy's Council it is not an executive but an advisory body, designed to bring the war effort in the Provinces and States into more direct and effective touch with the Central Government. Except for one representative of European commerce and another of the resident Anglo-Indian community, it is purely Indian in composition. It includes the Prime Ministers of four of the Provinces, representatives of labour, capital and agriculture, and well-tried champions of the depressed classes. Perhaps its most striking feature is the inclusion of a gifted Muslim lady - a wise appointment justified by a fine record of public service, and a fitting recognition of the swift and splendid awakening of India's womanhood.

These representatives of British India are to be joined on the Defence Council by representatives of the Indian States-that vast Indian India which, though an integral part of India, is not British India at all but under the rule of hereditary chiefs and princes. Who can doubt that India's war effort, already far greater than any one could have prophesied two years ago, will rapidly increase in vigour and magnitude, now that some of the best minds in the Provinces and the Indian States are to combine in a joint endeavour to stimulate it?

But the strengthening of the Central Government and the intensification of India's war effort are not all that may be looked for from this influx of Indians into the Viceroy's Council and this gathering of Indians from Provinces and States in a National Defence Council. It is not too sanguine to hope that these innovations will help to prepare the ground for the even more difficult task of constitution-building that lies ahead of India. To-day what stands in the way of India's selfgovernment and evolution to her full status is, as Mr. Amery put it, "the absence of any willingness among Indians themselves to agree upon the lines on which they will govern themselves". Hitherto the rock of stumbling has been India's intolerance of her own diversity. But we in Britain have learnt that there is nothing like joint work for a supreme cause in a supreme crisis to bring about understanding of our political opponents, tolerance of their views, and a silent revolution in our own; and Executive Council and Defence Council alike will afford such joint work in plenty.

The characteristics of English-speaking peoples -and political India, be it remembered, is an English-speaking people-were summed up in memorable words by a statesman speaking in London a few weeks ago. "English-speaking countries are peopled by men and women of diverse nationalities and difierent religions. Their strength comes. from diversity, and their freedom is born of tolerance-tolerance of other people's origins, other people's religions, other people's ideas. It is the crowning virtue of English-speaking countries that they recognize and respect virtue wherever they find it, and are not inclined to beguile themselves with a primitive and barbaric idea that they themselves have a monopoly of it."

These are the words of one whom many Indians in the ranks both of labour and capital know well. They are not the words of an Englishman. They are the words of the late head of the International Labour Office, now the American Ambassador in London. No words could better sum up the spirit in which all lovers of India long to see political India set itself to the task of working out India's salvation. The future of India, that great cosmos of nations, cannot lie in any one race or religion or party claiming for itself the monopoly of political wisdom and authority. India's salvation can only lie in the Indian's tolerance of other Indians' origins, religions, ideas. In India's rich diversity, in India's triumphant unity in diversity lies-who can doubt it?-her future strength. 